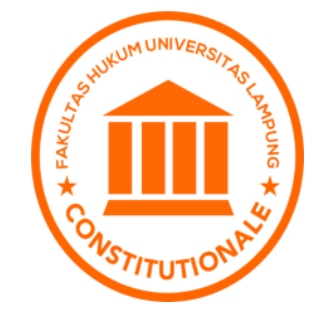

\title{
CONSTITUTIONALE
}

Volume 2 Issue 1, January-June 2021: PP: 69-78

Faculty of Law, Universitas Lampung, Bandar Lampung, Indonesia.

http://jurnal.fh.unila.ac.id/index.php/constitutionale

P-ISSN: 2723-2492 E-ISSN: 2745-9322

\section{Legal Problems on Regional Head Election during COVID-19 Pandemic in Indonesia}

\author{
Nilla Nargis \\ nilla.nargis@fh.unila.ac.id \\ Universitas Lampung, Indonesia
}

M. Iwan Satriawan

i_santri@yahoo.co.id

Universitas Lampung, Indonesia

Submitted: 7 January 2021; Reviewed: 14 March 2021; Accepted: 15 April 2021

Article's Information

Keywords: Election; Regional; Pandemic; Covid19.

DOI:

https://doi.org/10.25041/constitutionale.v2i1.2200
Abstract

The problem of the Covid-19 disease outbreak in Indonesia is of particular concern. This epidemic caused political and economic shocks to the state administration system. The problems that exist are related to the implementation of the Regional Head Election during the pandemic. This paper aims to find out the legal issues of regional head elections during a pandemic. The method used is the normative juridical method. The results of this paper show that the legal problem lies in the aspect of regulatory implementation. The government must continue to work hand in hand with handling the covid-19 outbreak and still prioritize the health of Indonesian citizens. Of course, the implementation of Regional Head Election does not violate the law based on Regulation in Lieu of Law No.2 of 2020 concerning the third amendment to Law No.1 of 2015 concerning 
Regional Head Election.

\section{A. Introduction}

Since Indonesia was recognized as an independent and sovereign country on 17 August $1945,{ }^{1}$ Through the 1945 Constitution (which was passed on 18 August 1945), the founding people have determined that the Unitary State of the Republic of Indonesia (hereinafter referred to as NKRI) adheres to the ideology or teachings of democracy. In Indonesian democracy, sovereignty (supreme power) is in the hands of the people and is fully implemented by the House of Representatives. This means that the Republic of Indonesia is classified as a country that adheres to representative democracy. ${ }^{2}$ Since the existence of reforms, supreme sovereignty is not only carried out by the MPR but carried out by other state organs based on law. ${ }^{3}$

Regional Heads (Governors, Regents, Mayors) are known in countries worldwide with different designations. In federal nations such as the United States, Governor is the head of state government. In contrast, in unitary states such as Indonesia, it is known as the head of regional government and hereinafter referred to as the head of the region. ${ }^{4}$ Regional head elections in Indonesia experience their dynamics. Starting from being elected by the president as in the early days of the independence revolution because it did not allow elections to be held, then the DPRD was elected in the New Order era until then it was directly elected by the people based on Law No.32 of 2004 as later replaced by Law No.10 of 2016 concerning elections. Governor, Deputy Governor, Mayor, Deputy Mayor, and Regent / or Deputy Regent, which the general public can easily refer to by the Regional Head Election Law. ${ }^{5}$ The direct election of regional heads is a new institutional framework in realizing the democratization process in the regions. ${ }^{6}$ It is hoped that this process can reduce widely the existence of power hijacking carried out by political parties that have seats in the House of Representatives or Dewan Perwakilan Rakyat Daerah (DPRD). In addition, direct regional elections are also expected to produce regional heads who have higher accountability. ${ }^{7}$

The development of regional elections in Indonesia has encountered obstacles related to the increasing spread of the Covid-19 virus pandemic. What initially had to be carried out in September 2020 had to be postponed to 9 December $2020 .{ }^{8}$ In addition to seeing the development of the spread of the coronavirus, whether it is increasing or decreasing, it is also related to the impossibility of the central government inaugurating the Person in Charge in

\footnotetext{
${ }^{1}$ To get the recognition that an independent state called Indonesia was established in the Southeast Asia region on 17 August 1945, the new Indonesian government under the leadership of Soekarno and Hatta tried to get support from countries in the world. As initial support, there has been recognition from the states of Egypt, Palestine, and India regarding the existence of the Indonesian state as an independent state. Read further details in Hatta, M.Untuk Negeriku (Menuju Gerbang Kemerdekaan),Jakarta,Gramedia Kompas,2015

${ }^{2}$ Rambe,K.Z Perjalanan Panjang Pilkada Serentak, Expose,2016,pg.7

3 Yusmiati Yusmiati, "KELEMBAGAAN NEGARA REPUBLIK INDONESIA MENURUT UNDANGUNDANG DASAR 1945," NUSANTARA : Jurnal Ilmu Pengetahuan Sosial 4, no. 1 (April 2, 2018): 62, https://doi.org/10.31604/jips.v4i1.2018.62-56.

${ }^{4}$ Zainal Arifin Hoesein dan Rahman Yasin,Op.Cit,pg.1

${ }^{5}$ Nandang Alamsah Deliarnoor, "Problematika Pelaksana Tugas (Plt) Dalam Masa Transisi Pemerintahan (Pra Dan Pasca Pilkada Serentak)," CosmoGov 1, no. 2 (2017): 322, https://doi.org/10.24198/cosmogov.v1i2.11841.

${ }^{6}$ Cornelis Lay, "Pilkada Langsung Dan Pendalaman Demokrasi," Jurnal Ilmu Sosial Dan Ilmu Politik 11, no. 1 (2007): 63-92, https://doi.org/10.22146/JSP.11003.

7 Ridho Imawan Hanafi, "PEMILIHAN LANGSUNG KEPALA DAERAH DI INDONESIA: BEBERAPA CATATAN KRITIS UNTUK PARTAI POLITIK ," Jurnal Penelitian Politik 11, no. 2 (2014), http://ejournal.politik.lipi.go.id/index.php/jpp/article/viewFile/197/81.

${ }^{8}$ Lihat dalam UU Nomor 6 Tahun 2020 tentang penetapan Perppu Nomor 2 Tahun 2020 tentang Perubahan Ketiga UU Nomor 1 Tahun 2015 tentang Pilkada Serentak.
} 
270 local governments covering 9 provinces, 37 cities, and 224 regencies throughout Indonesia. Because the law of an emergency where the wheels of government do not function empirically can be broken with the term Work From Home (WFH), as for the digital era and technological advances, work does not have to be face-to-face but can be through the zoom meeting application, google classroom or others for school children and so on. So that the service can still be carried out even though, in some ways, it is not optimal due to signal interference or because the community's ability in technology literacy is still not evenly distributed. ${ }^{9}$

As a legal umbrella for postponing the implementation of regional elections, the government has also issued Government Regulations in Lieu of Laws No.2 of 2020 concerning the amendments to the Third Law No.1 of 2015 concerning simultaneous regional head election, which was then followed by the General Election Commissions or Komisi Pemilihan Umum (KPU) by issuing KPU Regulation No.10 of 2020 concerning Amendments to the General Election Commission Regulation No. 6 of 2020 concerning the Implementation of Elections for Governors and Deputy Governors, Regents and Deputy Regents, and/or Mayors and Deputy Mayors Simultaneously Continuing in Non-Alam Disaster Conditions Corona Virus Disease 2019 (COVID-19).

According to Rezky, who analyzed the provisions of the legislative regulations on regional elections, it was stated that there is a mechanism that can be implemented if there are conditions that compel or allow the regional head election stage to be postponed. The choice is in the form of a follow-up election and a follow-up election. ${ }^{10}$ Various phenomena of the simultaneous regional elections amid the Covid-19 pandemic have raised juridical problems both from the human rights side, namely regarding the health rights of the community or the running of the wheels of government with the presence of a new regional head or also in the formulation of laws and regulations related to various Government Regulations in Lieu of Laws issued by opposing governments, on the one hand, the Government Regulations in Lieu of Laws on the enforcement of the covid protocol but on the other hand there is also a Government Regulations in Lieu of Laws on the implementation of regional head elections which the author will raise as a discussion in this paper.

This paper uses a normative juridical method. The data collection technique uses literature study collection techniques that come from books, articles, journals, laws, and various news from the mass media, both printed and electronic, as well as documents that are spread both in the KPU, Election Honorary Council, or Dewan Kehormatan Penyelenggara Pemilu DKPP) and Election Supervisory Agency or Badan Pengawas Pemilu (Bawaslu) and the central and regional governments, which later the authors analyzed following the needs of writing this paper.

\section{B. Discussion}

\section{The Dynamic of Regional Head Election in Indonesia}

General elections are both the essential means of democratization. However, the manifestation of democracy will be felt in real terms when the general election process is held to determine the leader candidate who deserves to hold the reins of power. ${ }^{11}$ Because without

\footnotetext{
${ }^{9}$ Ardika Nurfurqon, "Analisis Kebijakan Pemerintah Daerah Dalam Penanganan Covid-19: Perspektif Hukum Administrasi Negara," JURNAL YUSTIKA: MEDIA HUKUM DAN KEADILAN 23, no. 01 (September 16, 2020): 13-23, https://doi.org/10.24123/yustika.v23i01.2864.

${ }^{10}$ Rezky Panji Perdana Martua Hasibuan, "Urgensitas Perppu Pilkada Di Kala Wabah Pandemi Covid-19," 'ADALAH 4, no. 1 (2020), http://www.journal.uinjkt.ac.id/index.php/adalah/article/view/15503.

11 Zubakhrum B.Tjenreng, Demokrasi di Indonesia Melalui Pilkada Serentak, Depok,Papas Sinar Sinanti, 2020,pg.27
} 
democracy, a country will experience a dictatorial or monarchical system due to a change of leader through appointment or coup. For countries that declare themselves as countries with modern democracies, general elections (elections) are the primary mechanism present in organizing elections and forming a government. Because without democracy, a country will experience a dictatorial or monarchical system due to a change of leader through appointment or coup. For countries that declare themselves as countries with modern democracies, general elections (elections) are the main mechanism that must be present in organizing elections and forming a government. ${ }^{12}$

The limitation of power through the conduct of elections in several countries has varying applications. Some are once every 4 (four) years, such as the Philippines and the United States, but some are once every 5 (five) years, like Indonesia. Even in some countries, if they have been elected for the same two terms of office, they cannot be re-elected for the third time to provide opportunities for other citizens to participate in building the country through the general election of the head of state. ${ }^{13}$ In the context of the development of the application of democracy, the perspective of regional head elections is a drama that has contextual episodes with political dynamics in the transition to democracy in Indonesia. All parties must be wise in evaluating each of these episodes because, in a democratic transition, the choices of applying democracy as part of the political dynamics are directly proportional to the dynamic conditions both at home and in dynamic global conditions. This transitional period was marked by liberalization and democracy. ${ }^{14}$ As said by Larry Diamond, the local government has a vital role in accelerating the vitality of democracy. Diamond provides several reasons that local government can help develop values and democratic skills among its citizens. Local government can also increase accountability and accountability to various interests that exist in the region. Also, local governments can provide additional channels and access to historically marginalized groups. ${ }^{15}$

Based on Law Number 1 of 1945, regional head elections are carried out by the council. Meanwhile, according to Law Number 22 Year 1948, regional heads are elected by the central government from the candidates submitted by the Regional House of Representatives or Dewan Perwakilan Rakyat Daerah (DPRD). The DPRD has the right to propose the dismissal of a regional head to the central government. However, since the enactment of Law Number 1 of 1957 to Law Number 5 of 1974, the provisions for regional head elections have not changed with the following provisions: ${ }^{16}$

(1) DPRD elects the regional head;

(2) The head of a level I region is appointed and dismissed by the president

(3) The head of a level II region is appointed and dismissed by the Minister of Home Affairs and regional autonomy from the candidates submitted by the DPRD concerned.

In the New Order era, the position of the regional head often only revolved around three main axes, namely ABG (ABRI, Bureaucrats, and Golkar). The existence of this dispatched regional head cannot be separated from the floating mass political model. ${ }^{17}$ (floating mass) The centralization of power practiced by the Soeharto regime with the main vehicle of the

\footnotetext{
${ }^{12}$ Gaffar, J. M,Politik Hukum Pemilu,Jakarta,Konstitusi Press,2013,pg.36

${ }^{13}$ Rokiyah, "Make an Honorary Board of Election Organizers (DKPP) as a Special Election Justice," Journal of Law, Policy and Globalization, March 2019, https://doi.org/10.7176/jlpg/83-10.

${ }^{14}$ Hoesein,Z,A\&Yasin,R.2015.Pemilihan Kepala Daerah Langsung(Penguatan Konsep dan Penerapannya),Jakarta Timur,LP2AB,hal.2

${ }^{15}$ Ibid,

${ }^{16}$ Suharizal, Pemilukada (Regulasi, Dinamika dan Konsep Mendatang), (Jakarta:Rajawali Press,2012),pg 16

${ }^{17}$ The floating mass politics practiced by the Soeharto regime was inseparable from the issuance of Law No.3 of 1975 on Political Parties and Golkar or better known as the fusion of political parties.
} 
Golkar party, which is 6 (six) elections from 1971 to 1997, always controlled more than 50\% of the parliament.

Entering the reform era in 1998, there has been a significant change in the Indonesian constitution, namely the amendment of the 1945 Constitution, especially in article 18 paragraph (4), which states that "Governors, Regents, and Mayors as heads of provincial, regency and city governments are elected democratically". Based on the sound of article 18 paragraph (4) of the 1945 Constitution, and seeing the success of the direct presidential and vice-presidential elections in 2004, the people's representatives (DPR) agreed that regional head elections could also be carried out directly, which began in 2007 for the Jakarta regional head election. The 1945 Constitution of the Republic of Indonesia has placed the people as the owner of sovereignty. The implementation of people's sovereignty is carried out by indirectly electing leaders, both the president and vice president, governors, regents/mayors, and village heads. At the people's representative institutions, they are given honor and become a political right to elect representatives of the people who sit in representative institutions starting from the DPD RI, DPR RI, Provincial DPRD Regency/City DPRD to BPD.

Philosophically, direct regional head elections in districts/cities and provinces are to position local government units in a strong position as a part of the constitutional structure of the Republic of Indonesia, which has legitimacy from the constitution (not a gift from the central government), to produce governors and regents, and the mayor who works entirely for the welfare of the people. ${ }^{18}$ Over time, the regional head elections were then held simultaneously in a gradual manner, with the first batch being held in December 2015 (for the end of the 2015 term of office and the first semester of 2016). The second batch will be held in February 2017 (for the end of the 2017 term). The third batch will be held in June 2018 (for those with the end of the 2018 term and the end of 2019). The fourth batch will be held in 2020 (for regional heads from the December 2015 regional elections). The fifth batch will be held in 2022 (for regional heads from the February 2017 regional elections). The sixth batch will be implemented in 2023 (for regional heads from the 2018 regional elections). In the seventh wave, the regional elections will be held simultaneously nationally in $2027 .{ }^{19}$

\section{Juridical Problems in Simultaneous Regional Election in the Middle of the Covid-19 Pandemic}

There was a tug of war between the central government and several local governments, which were partially supported by several religious organizations and NGOs related to the simultaneous regional elections in the middle of the COVID-19 pandemic, which began in March 2020 until when this article was written in November 2020, there were no signs of its repeal. Covid-19 pandemic free status. ${ }^{20}$ Either prioritizing health protection for the community or promoting the running of the wheels of government both at central and regional levels. ${ }^{21}$ Because in practice, several regions have implemented a curfew ${ }^{22}$ until the enactment

\footnotetext{
${ }^{18}$ Sri Nuryanti, "Intervensi Penyelenggaraan Pemilukada: Regulasi, Sumberdaya Dan Eksekusi," Jurnal Ilmu Sosial Dan Ilmu Politik 19, no. 2 (April 5, 2016): 125, https://doi.org/10.22146/jsp.10849.

${ }^{19}$ Rambe Kamarul Zaman, Op.Cit,pg.25

${ }^{20}$ Putu Sekarwangi Saraswati, "Kebijakan Hukum Terhadap Penanganan Pandemi Covid-19 Di Indonesia," KERTHA WICAKSANA 14, no. 2 (July 23, 2020): 147-52, https://doi.org/10.22225/kw.14.2.1923.147-152.

${ }^{21}$ Wicipto Setiadi, "PENUNDAAN PEMILIHAN KEPALA DAERAH PADA MASA PANDEMI COVID-19 DALAM PERSPEKTIF HUKUM ADMINISTRASI NEGARA," Jurnal Rechts Vinding: Media Pembinaan Hukum Nasional 9, no. 3 (December 8, 2020): 427, https://doi.org/10.33331/rechtsvinding.v9i3.514.

${ }^{22}$ Bahkan demi menurunkan kasus covid-19 Pemerintah Kota Bogor menerapkan Jam malam.Baca dalam https://m.liputan6.com/news/read/4349383/ada-jam-malam-bima-arya-sebut-kasus-covid-19-di-kota-bogor$\underline{\text { menurun }}$
} 
of the Large-Scale Social Restrictions or Pembatasan Sosial Berskala Besar (PSBB), ${ }^{23}$ To reduce the number of sufferers and the spread of the Covid-19 outbreak. ${ }^{24}$ Under these conditions, several countries also continue to hold elections both at the national and local levels. This can be a comparison of public participation in elections amid a pandemic in Indonesia. The following table states the level of public participation in elections in several countries in the world.

Table 1

Comparison of Voter Participation Pre and Post

The Covid-19 Pandemic ${ }^{25}$

\begin{tabular}{|c|c|c|c|c|c|}
\hline No & State & $\begin{array}{l}\text { Voting } \\
\text { Type }\end{array}$ & $\begin{array}{c}\text { Execution } \\
\text { Date }\end{array}$ & Voters & $\begin{array}{c}\text { Previous } \\
\text { Election } \\
\text { Vote }\end{array}$ \\
\hline 1. & Iran & Parliament & $\begin{array}{c}21 \text { February } \\
2020\end{array}$ & $42,32 \%$ & $60,09 \%$ \\
\hline 2. & $\begin{array}{c}\text { Dominican } \\
\text { Republic }\end{array}$ & President & $\begin{array}{l}15 \text { March } \\
2020\end{array}$ & $55.18 \%$ & $67.77 \%$ \\
\hline 3. & Vanuatu & Parliament & $\begin{array}{l}19 \text { March } \\
2020\end{array}$ & $51,29 \%$ & $56,47 \%$ \\
\hline 4. & Guinea & Parliament & $\begin{array}{l}22 \text { March } \\
2020\end{array}$ & $58,04 \%$ & $63,53 \%$ \\
\hline 5. & $\begin{array}{c}\text { Queensland } \\
\text { Australia }\end{array}$ & $\begin{array}{c}\text { Local } \\
\text { Election }\end{array}$ & $\begin{array}{l}29 \text { March } \\
2020\end{array}$ & $77-78 \%$ & $83 \%$ \\
\hline 6. & Mali & Parliament & $\begin{array}{l}29 \text { March } \\
2020\end{array}$ & $35,58 \%$ & $38,50 \%$ \\
\hline 7. & South Korea & Parliament & $\begin{array}{l}15 \text { April } \\
2020\end{array}$ & $66,21 \%$ & $58,03 \%$ \\
\hline 8. & Serbia & Parliament & 21 June 2020 & $48,93 \%$ & $56,07 \%$ \\
\hline 9. & Iceland & Parliament & 27 June 2020 & $66,92 \%$ & $75,67 \%$ \\
\hline 10. & Croatia & Parliament & 5 July 2020 & $46,90 \%$ & $52,59 \%$ \\
\hline 11. & Singapore & Parliament & 10 July 2020 & $95,81 \%$ & $93,70 \%$ \\
\hline 12. & Poland & President & 12 July 2020 & $68.18 \%$ & $55.34 \%$ \\
\hline
\end{tabular}

Source: International IDEA

Based on the data above, there is indeed a significant influence on the Covid-19 pandemic on the level of voter participation in elections in several countries, ${ }^{26}$ and compared with the incidence of elections in Indonesia during the reform era are as follows: ${ }^{27}$

\footnotetext{
23 The DKI government has implemented the PSBB based on the Decree of the Governor of DKI Number 88 of 2020 concerning amendments to the Governor Regulation No. 33 of 2020 concerning PSBB in DKI Jakarta.

24 Latipah Nasution, "Hak Kesehatan Masyarakat Dan Hak Permintaan Pertanggungjawaban Terhadap Lambannya Penanganan Pandemi Global Coranavirus Covid-19 ," 'ADALAH 4, no. 1 (2020), http://103.229.202.71/index.php/adalah/article/view/15384.

${ }^{25}$ file:///C:/Users/User/AppData/Local/Temp/PilkadaPandemiDanPengalamanNegaraLain.pdf

26 Namun berbeda dengan Amerika Serikat yang baru saja melaksanakan pemilu presiden tahun 2020 dimana akhirnya masyarakat Amerika mempunyai Presiden baru yaitu Joe Biden dari partai Demokrat. Partisipasi pemilih dalam pilpres kali ini sangat bagus dibandingkan pilpres periode yang lalu. Baca dalam https://www.bbc.com/indonesia/dunia-54783876
} 


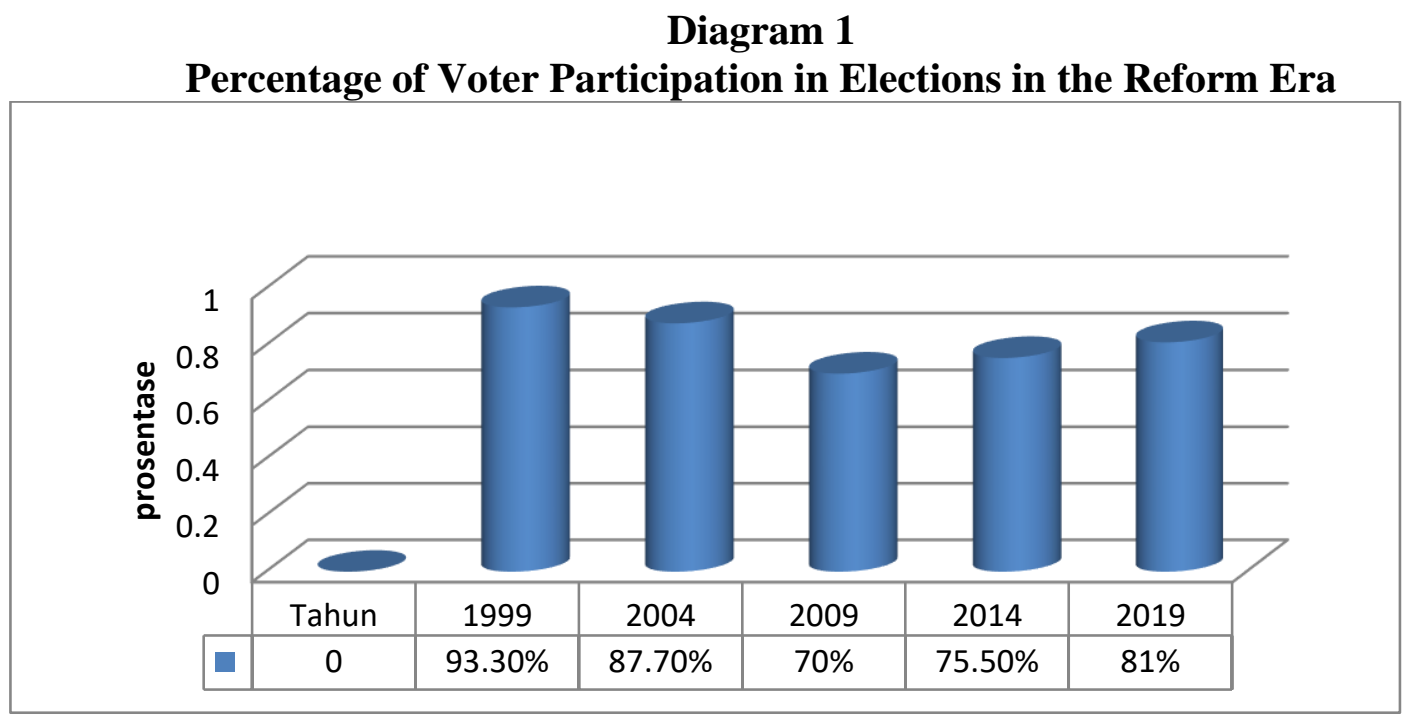

The data above shows that the level of voter participation in Indonesia is unstable from year to year because this is not only influenced by the quality of the candidates but also by the suboptimal performance of election administrators. Meanwhile, the impact of emergencies due to disease outbreaks or disasters has never occurred in Indonesia. Reflecting on the election organizers in countries affected by the pandemic, some countries have increased their voter turnout rates, but some have decreased. ${ }^{28}$ With these conditions, the implementation of regional elections in Indonesia, which is full of limitations due to the Covid-19 pandemic, is predicted to decline, but this will not reduce the legality of the election of regional heads from the 2020 regional elections. ${ }^{29}$

Because with our current election system, the regional head elections are based on a one man one vote system, even though many people do not come to the polling station or the level of participation is only $40 \%$ of the total population in a specific area. Regions then the regional elections are still considered valid and regional heads elected with only $30 \%$ of the total valid votes will still be inaugurated as regional heads with a term of 5 (five) years which has the same legitimacy as regional heads who have more than $80 \%$ of the votes. ${ }^{30}$

\section{Conclusion}

The implementation of regional head elections always experiences its dynamics depending on the context in which and when the elections are held, like the implementation of the simultaneous regional elections in 2020, which was held amid the Covid-19 epidemic that has hit the whole world not only Indonesia. So it becomes an equally difficult choice for the government between protecting its citizens from the attack of the Covid-19 pandemic or then promoting the running of government organizations by continuing to carry out regional

\footnotetext{
${ }^{27}$ Agus Dedi, “ANALISIS SISTEM PEMILIHAN UMUM SERENTAK," Jurnal MODERAT, vol. 5, September 11, 2019, https://doi.org/10.25147/MODERAT.V5I3.2676.

${ }^{28}$ Dániel Oross Dániel Mikecz, "Political Participation, Volunteering During the COVID-19 Pandemic in Hungary," Corvinus Journal of Sociology and Social Policy 11, no. 2 (2020): 175-77.

${ }^{29}$ Muh Hasrul, "ASPEK HUKUM PEMBERLAKUAN PEMBATASAN SOSIAL BERSKALA BESAR (PSBB) DALAM RANGKA PENANGANAN CORONA VIRUS DISEASE 2019 (COVID-19)," Jurnal Legislatif, June 22, 2020, https://journal.unhas.ac.id/index.php/jhl/article/view/10477.

${ }^{30}$ T Heru Nurgiansah, "The Role of Citizenship Education in Building Bantul Community Political Participation in The Pandemic Covid 19," Social, Humanities, and Educational Studies (SHEs): Conference Series 4, no. 1 (February 22, 2021): 1, https://doi.org/10.20961/shes.v4i1.48558.
} 
elections simultaneously. After experiencing various public considerations and debates, the government decided to continue implementing the 2020 regional elections while adhering to the covid-19 protocol. So it becomes an equally difficult choice for the government between protecting its citizens from the attack of the Covid-19 pandemic or then promoting the running of government organizations by continuing to carry out regional elections simultaneously. After experiencing various public considerations and debates, the government decided to continue implementing the 2020 regional elections while adhering to the covid-19 protocol. And the implementation of the elections in the middle of the Covid-19 outbreak is not against the law because the Perppu No.2 of 2020 concerning the changes to the Third Law No.1 of 2015 concerning the Pilkada simultaneously is one of the political considerations so that the wheels of governmental organizations in the regions continue to run with the election. Definitive regional head.

\section{A. Books}

\section{Bibliography}

Gaffar, J. M. Politik Hukum Pemilu, Jakarta: Konstitusi Press. 2013.

M.Hatta. Untuk Negeriku (Menuju Gerbang Kemerdekaan),Jakarta: Gramedia Kompas. 2015.

Rambe,K.Z. Perjalanan Panjang Pilkada Serentak, Yogyakarta,Expose. 2016.

Suharizal, Pemilukada (Regulasi, Dinamika dan Konsep Mendatang), Jakarta: Rajawali Press. 2012.

Zainal Arifin Hoesein dan Rahman Yasin. Pemilihan Kepala Daerah Langsung, Jakarta: LP2AB. 2015.

Zubakhrum B.Tjenreng. Demokrasi di Indonesia Melalui Pilkada Serentak, Depok: Papas Sinar Sinanti. 2020.

\section{B. Journal}

Dániel Mikecz, Dániel Oross. "Political Participation, Volunteering During the COVID-19 Pandemic in Hungary." Corvinus Journal of Sociology and Social Policy 11, no. 2 (2020): 175-77.

Dedi, Agus. "ANALISIS SISTEM PEMILIHAN UMUM SERENTAK." Jurnal MODERAT. Vol. 5, September 11, 2019. https://doi.org/10.25147/MODERAT.V5I3.2676.

Deliarnoor, Nandang Alamsah. "Problematika Pelaksana Tugas (Plt) Dalam Masa Transisi Pemerintahan (Pra Dan Pasca Pilkada Serentak)." CosmoGov 1, no. 2 (2017): 322. https://doi.org/10.24198/cosmogov.v1i2.11841.

Hanafi, Ridho Imawan. "PEMILIHAN LANGSUNG KEPALA DAERAH DI INDONESIA: BEBERAPA CATATAN KRITIS UNTUK PARTAI POLITIK ." Jurnal Penelitian $\begin{array}{lllll}\text { Politik } & 11, & \text { no. } & 2 & \text { (2014). }\end{array}$ http://ejournal.politik.lipi.go.id/index.php/jpp/article/viewFile/197/81.

Hasrul, Muh. "ASPEK HUKUM PEMBERLAKUAN PEMBATASAN SOSIAL BERSKALA BESAR (PSBB) DALAM RANGKA PENANGANAN CORONA VIRUS DISEASE 2019 (COVID-19).” Jurnal Legislatif, June 22, 2020. https://journal.unhas.ac.id/index.php/jhl/article/view/10477.

Lay, Cornelis. "Pilkada Langsung Dan Pendalaman Demokrasi." Jurnal Ilmu Sosial Dan Ilmu Politik 11, no. 1 (2007): 63-92. https://doi.org/10.22146/JSP.11003.

Nasution, Latipah. "Hak Kesehatan Masyarakat Dan Hak Permintaan Pertanggungjawaban Terhadap Lambannya Penanganan Pandemi Global Coranavirus Covid-19 ." 'ADALAH 4, no. 1 (2020). http://103.229.202.71/index.php/adalah/article/view/15384.

Nurfurqon, Ardika. "Analisis Kebijakan Pemerintah Daerah Dalam Penanganan Covid-19: 
Perspektif Hukum Administrasi Negara." JURNAL YUSTIKA: MEDIA HUKUM DAN KEADILAN 23, no. $01 \quad$ (September 16, 2020): 13-23. https://doi.org/10.24123/yustika.v23i01.2864.

Nurgiansah, T Heru. "The Role of Citizenship Education in Building Bantul Community Political Participation in The Pandemic Covid 19." Social, Humanities, and Educational Studies (SHEs): Conference Series 4, no. 1 (February 22, 2021): 1. https://doi.org/10.20961/shes.v4i1.48558.

Nuryanti, Sri. "Intervensi Penyelenggaraan Pemilukada: Regulasi, Sumberdaya Dan Eksekusi.” Jurnal Ilmu Sosial Dan Ilmu Politik 19, no. 2 (April 5, 2016): 125. https://doi.org/10.22146/jsp.10849.

Rezky Panji Perdana Martua Hasibuan. "Urgensitas Perppu Pilkada Di Kala Wabah Pandemi Covid-19." 'ADALAH 4, no. 1 (2020). http://www.journal.uinjkt.ac.id/index.php/adalah/article/view/15503.

Rokiyah. "Make an Honorary Board of Election Organizers (DKPP) as a Special Election Justice." Journal of Law, Policy and Globalization, March 2019. https://doi.org/10.7176/jlpg/83-10.

Saraswati, Putu Sekarwangi. "Kebijakan Hukum Terhadap Penanganan Pandemi Covid-19 Di Indonesia." KERTHA WICAKSANA 14, no. 2 (July 23, 2020): 147-52. https://doi.org/10.22225/kw.14.2.1923.147-152.

Setiadi, Wicipto. "PENUNDAAN PEMILIHAN KEPALA DAERAH PADA MASA PANDEMI COVID-19 DALAM PERSPEKTIF HUKUM ADMINISTRASI NEGARA." Jurnal Rechts Vinding: Media Pembinaan Hukum Nasional 9, no. 3 (December 8, 2020): 427. https://doi.org/10.33331/rechtsvinding.v9i3.514.

Yusmiati, Yusmiati. "KELEMBAGAAN NEGARA REPUBLIK INDONESIA MENURUT UNDANG-UNDANG DASAR 1945." NUSANTARA : Jurnal Ilmu Pengetahuan Sosial 4, no. 1 (April 2, 2018): 62. https://doi.org/10.31604/jips.v4i1.2018.62-56. 
